\title{
RESEARCH CLASSIFICATION OF KARL REICHL
}

\section{Dilafruz Abdujamilovna Kalandarova}

Teacher, Department "Uzbek Language And Literature" Tashkent State Pedagogical University Named After Nizami, Uzbekistan

\section{ABSTRACT}

The article discusses the fact that the famous German scientist Karl Reichl is a modern researcher, a classification of research created in the framework of his work in the process of recording and studying scientific, scientific-pedagogical, folklore and ethnographic materials.

KEYWORDS: - Researcher, linguist, literary critic, folklorist, turkologist, polyglot scientist.

\section{INTRODUCTION}

In world folklore, scholars of European countries pay special attention to the oral art of the Turkic peoples, including the Uzbek people, and try to study it extensively. However, the translations and studies of a number of scholars who have worked on this subject, such as Herman Vambery, Corliss Lamont, Idris Shah, S. Bowra, Paksoy, H. B, Karl Reichl, Marilyn Petersen, have not yet been sufficiently studied [1., 418 p.].

\section{Methods}

Professor Karl Reichl has published more than 90 scientific articles in various scientific journals and collections around the world. Most of them are devoted to the study of medieval history, linguistics, folklore heritage of the Turkic peoples, the works of some poets. Karl Reichl has written more than 60 articles for various encyclopedias. He is the author of 96 scientific books.

Accordingly, the scope of Karl Reichl's research can be classified as follows:

1. Analysis and Interpretation of Religious Poetry. Part of Karl Reichl's research is devoted to the study of literary sources created during the Middle Ages. He took a special interest in medieval English and American literature. Due to this interest, in 1971 he received a doctorate in medieval medicine from the University of Munich. The subject of his dissertation for this title is the study of religious poetry in medieval English literature. The scholar published this study in 1973 in Munich as a book entitled Medieval English Poetry. In this research work, he focuses more on the religious poetry of late 
CURRENT RESEARCH JOURNAL OF PHILOLOGICAL SCIENCES 2(11):

29-33, November 2021

DOI: https://doi.org/10.37547/philological-crjps-02-11-08

ISSN 2767-3758

(C)2021 Master Journals

Crossref doi

gil Google

Accepted25 ${ }^{\text {th }}$ November, 2021 \& Published $30^{\text {th }}$ November, 2021

medieval England. The scholar's 1976 book, A Study of Medieval Latin Text, published in London, is also noteworthy in this regard.

2. A study of the linguistic features of the works of some poets and their works. An example of this is the scientist's research on the work of Robert Grosetters.

3. Research on the music of mystical works. Karl Reichl focused on the music of Richard Roll's mystical works in this regard.

4. Linguistic works. Karl Reichl's research for a professorship is directly related to the field of linguistics. The topic of his professorial dissertation on linguistics is "Grammar category and word formation". This study was published as a book in 1982 in Tubingen under the title The Laws of English Grammar.

From 1978 to 2008, Karl Reichl worked as a professor of medieval literature and historical linguistics at the Institute of American Studies and Cello at the University of Bonn. He is a great scholar who has attained the rank of professor, a wellknown specialist in historical linguistics. Due to his similar high scientific achievements in linguistics, the scientist was invited in 2011 to work as a professor of English at the University of WisconsinMadison.

5. His research on comparative literature. Karl Reichl was invited in 1990 to work as a professor at the Faculty of Comparative Literature at Harvard University in the United States and at the Faculty of Languages and Cultures at the University of the Middle East. In 1995, he worked as a professor at the Higher School of Practice in Paris, France. In 2007, he was invited as a professor at the Faculty of Islamic Studies and Middle East Studies at the Jewish University in Jerusalem, Israel. In 2009, he was invited to become a professor at the Faculty of Comparative Literature at the Jewish University in Jerusalem. He also worked as a researcher at the Institute for Social Research in the United States that same year. As a result of this work, the scientist was able to publish such books as "Dictionary of Medieval English Epics" (1993, Frankfurt), "Harmonious cases of prose and poetry in world literature" (1997, Cambridge).

6. Folklore: oral literature, Turkish oral epic poetry, research on the problems of oral epic. In this regard, the scholar's "Heroic Epic of the Turkic Peoples" (1992, New York), "Oral Epic Tradition: Styles and Forms" (2000, New York), "Articles on the Heroic Epic of the Turkic Peoples" (2000, New York), He has published a number of scientific works, such as "Epic Creativity and Music" (2000, Berlin), " Alpamysh " Uzbek folk heroic epic "(2002, Bonn). Even though his books on folklore are much larger than his books on other fields, it is clear that the scholar approached this field with special attention and interest. This is also evident in the experiments of the scientist on the study of worldfamous epics (Manas, Alpamysh, Gorogly, Edigo).

\section{Results AND DISCUSSIONS}

Karl Reichl's research on the epic Alpamysh is summarized in his book The Uzbek Heroic Epic of Alpamysh. The book was published in Uzbek and German in Bonn. The book contains the original text, translation, research and a large section of the book "Uzbek versions of the epic" Alpamysh "by Professor Tora Mirzaev." The presentation of this book also took place at the University of Bonn. A group of Uzbek scientists led by Tora Mirzaev, People's Artist of Uzbekistan Shoberdi Boltaev and embassy staff also took part in it.

As Karl Reichl rightly admits, the first task of Uzbek folklorists was to preserve this great treasure for generations. "It is no exaggeration to say that such a huge treasure is a great heritage that is rarely shared by nations. What has been published from this great heritage to this day is just a drop in the ocean," he said. 
CURRENT RESEARCH JOURNAL OF PHILOLOGICAL SCIENCES 2(11):

29-33, November 2021

DOI: https://doi.org/10.37547/philological-crjps-02-11-08

ISSN 2767-3758

(C)2021 Master Journals

\section{Crossref do}

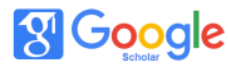

Accepted $25^{\text {th }}$ November, 2021 \& Published $30^{\text {th }}$ November, 2021

When Karl Reichl came to Uzbekistan, he conducted his research under the scientific guidance of Tora Mirzaev. In the summer of 1988 he worked with Tora Mirzaev in the Folklore Department of the Institute of Literature in Tashkent. That is why he considered the well-known Uzbek folklorist Tora Mirzaev as his teacher and friend. Tora Mirzaev acknowledged that the books "Uzbek versions of the epic Alpamysh " and "Epic repertoire of folk singers" are undoubtedly an important guide in the study of not only Uzbek folklore, but also the epic works of the peoples of the world. Therefore, they were widely used. He even translated some of them and intended that they would be used by folklorists around the world.

"It's not just my confession," he said. You can see this recognition in Russian, Turkish and American scientists as well," he said. In Putilov's latest book, Epic Creativity, he cites excerpts from Tora Mirzaev's books in more than 300 places. He emphasizes that this single example alone determines the level of Uzbek folklore.

Karl Reichl also conducted a number of researches on Uzbek bakhshis and epics. His 1992 study, The Heroic Epic of the Turkic Peoples, was published in English in New York. In this book, more Bakhchisaray traditions, the peculiarities of the heroic epic of the Turkic peoples are described.

From 1978 to 1988, he was a member of the "Sonderforschungsbereich" Special Research Group for Central Asia at the University of Bonn. In 1975 he was accepted as an honorary professor of Nukus State University named after Berdakh in the capital of Karakalpakstan. In 1999 he was admitted to the North Rhine-Westphalian Academy of Sciences. Since 2010, he has been a scientific adviser at the Institute of Ethnic Literature of the Chinese Academy of Social Sciences in Beijing, the capital of the Chinese state. In this regard, his lecturing activities not only at the University of Bonn, but also abroad can be noted. This information directly constitutes the professional biography of the scientist.

The fact that Karl Reichl is a modern scientific researcher is also evident in the example of the books he created. In particular, the scientist seriously tried to prove every scientific point of view, expressed in his first book "Uzbek folk tales" (1976, Bochum), based on the requirements of modern folklore, comparative literature, Turkic studies, translation, advanced research methods of these disciplines. his approach, his efforts to provide the contents of the book with the necessary commentaries and dictionaries, and his serious attention to the quality of the translation of fairy tales allow the scholar to be highly praised.

It should be noted that the main feature of Karl Reichl's books is that the ideological and artistic features of this or that epic work (fairy tale or epic) are combined with a comprehensive analysis of the original and translated text of the sample. In this way, the scientist made a significant contribution to the development and strengthening of scientific and theoretical principles of publishing folklore works in two languages - unrelated to each other, in a foreign language related to different systems. His publications on the subject have been published in Uzbek and German, as well as in Uzbek and English. It should also be noted that for the first time in Uzbek folklore, Karl Reichl began the practice of publishing his translation together with a CD of his live performance (sung by Bakhshi or Jiraw) [2.,1720 p.].

As T. Mirzaev admitted: "This is the first edition of Uzbek and Karakalpak epics with a CD.

Karl Reichl is a polyglot, a scientist who speaks many languages. Karl Reichl is fluent in English, 
CURRENT RESEARCH JOURNAL OF PHILOLOGICAL SCIENCES 2(11):

29-33, November 2021

DOI: https://doi.org/10.37547/philological-crjps-02-11-08

ISSN 2767-3758

(C2021 Master Journals

\section{Crossref do:}

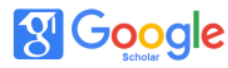

Accepted $25^{\text {th }}$ November, 2021 \& Published $30^{\text {th }}$ November, 2021

Turkish (Turkish, Karakalpak, Kyrgyz, Kazakh, Uzbek) in addition to his native German. He speaks Turkish, Uzbek, Uyghur, Karakalpak, Kazakh and Kyrgyz Turkmen. The scientist was also interested in learning English, French and Chinese, which are world languages. For this purpose, from 1963 to 1968 he studied English and Roman philology at the universities of Munich, Germany and Montpellier, France. In 1968, he successfully passed the state exams in English and French. He then studied natural sciences at Magdalena College at Cambridge University from 1968 to 1970 . From 1971 to 1977 he worked as an associate professor at the University of Munich.

As a Turkologist, Karl Reichl paid special attention to the study of Turkic languages. In particular, he took a special interest in the features of Turkic languages. He also studied Persian.

In 1976, he was on a scientific trip to Leningrad (now St. Petersburg) and began to study Russian independently. Especially after the acquisition of the book "Turkish Heroic Epic" by the Russian scientist, academician V.M Zhirmunsky, his interest in learning the Russian language increased.

Karl Reichl arrived in Tashkent, Uzbekistan for the first time in 1981 under a plan to exchange researchers as part of the Soviet-German cultural and scientific exchange program. According to Mirzaev, at that time he had published a book on Uzbek folk tales and had risen to the level of a folklorist who could speak Uzbek and Russian fluently.

During this trip, Karl Reichl worked in the archive of Uzbek folklore at the Department of Folklore of the Institute of Literature of the Academy of Sciences of Uzbekistan in Tashkent. He recorded samples of folklore from the repertoire of Uzbek bakhshis and Karakalpak jiraws. On this basis, he conducted research under the guidance of Professor Tora Mirzaev. Then he continued his research at the Karakalpak branch of the Academy of Sciences of Uzbekistan under the guidance of Professor Kabil Maksudov.

Thus, he visited Tashkent and Nukus several times. He lived in Nukus for some time. During this visit, Karl Reichl recorded some examples of Uzbek and Karakalpak folklore live. In particular, during his folklore expedition to Karakalpakstan in 1981, he recorded the epic "Edigey" from the Karakalpak poet Jumaboy Bozorov (1927-2006) for the first time on a modern tape recorder. The scientist also managed to record almost all other epics in the repertoire of Jumaboy Bozorov.

\section{Conclusion}

In short, Karl Reichl is a well-known German philologist, orientalist, turkologist. His work as a researcher of epic works, a researcher of Manas, stands out. Not only his significant scientific research in folklore, literature and linguistics, but also his translations from the oral literature of different peoples, his views on ancient literature, their language, art, music are very valuable.

\section{ReFERENCES}

1. Vambery A. Scenes from the East (Through the Eyes of a European traveler in 1860), Corvina, Kiads, - Budapest, 1979. - 418 p.;

2. Vambery A. Sketches of Central Asia. London, 1868. - 444 p.; Vambery A. Travels in Central Asia. - London, 1996. - 443 p.;

3. Lamont C. The Peopleds of the Soviet Union. New York, 1946. - 229 p.;

4. Shah I. The Pleasantries of Incredible Mulla Nasrutdin. - London, 1974;

5. Bowra C. Heroic Poetry. London, 1961. - 808 
CURRENT RESEARCH JOURNAL OF PHILOLOGICAL SCIENCES 2(11):

29-33, November 2021

DOI: https://doi.org/10.37547/philological-crjps-02-11-08

ISSN 2767-3758

(C)2021 Master Journals

crossref do) 8: Google

Accepted25 $5^{\text {th }}$ November, 2021 \& Published 30th November, 2021

p.;

6. Paksoy H.B. "Alpamysh" Central Asian

Identity under Russian Rule", USA, AACAR, 1989. - 683 p.;

7. Reichl Karl. Turkic Oral Epic Poetry: Traditions, Forms, Poetic Structure. Garland Publishing,inc. - New York \& London, 1992. 395 p.;

8. Uzbekische Maerchen. Herausgegeben und uebersetzt von Karl Reichl. - Bochum, 1978;

9. Maerchen der Usbeken: Samarkand, Buhara, Taschkent. Herausgegeben und uebersetzt von I.L.Cirtautas. Koeln, 1984;

10. Reichl K. Uzbek Epic Poetry: Traditions and Poetic Diction. - Hainsworth, 1989;

11. Petersen Marilyn. Treasury of Uzbek Legends and Lore. - Tashkent: Qatortol-Kamolot, 2000. - $180 \mathrm{p}$.

12. Mirzaev T. Karl Reichl is a researcher of Uzbek folklore. - Uzbek language and literature. - 2013. - №4. - p.17-20. 